\title{
第10回 日本オージオロジー学会総括報告
}

本報告は各群ごとに報告者 (末尾)により記載されたものでありますが，文中氏名に対する敬称は すべて省略してあります故, '会員各位にはよろしく御了承いただきます。

(日本オージオロジー学会編集委員会)

\section{第 1 群}

脳波上の聴性反応をよりり明確にとらえるために電子 加算装置を利用する方法が極く最近本邦でも急速に取 入れられるようになったが，本群ではこれらの基礎 的, 臨床的問題が発表された。

生ず安野等 (京都府大) 注成人営醒時において, 種々の条件の音刺激と反応の大きさとの関係, 及び音 刺激に対する馿れの問題を述べたが，これに対し吉江 （信大）は誘発電位の入出力関係は条件をととのえれ

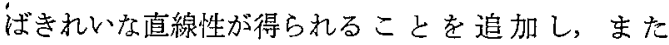
habituationにつき被検者によるバラッキが相当あり 短時間の検查では，一定傾向は得難いと述心゙，また反 忘の大きさのとり方を質したが，伊藤は $\mathrm{P}_{1} \sim \mathrm{N}_{2}$ をと ったと答えた。

田口（信大）は乳児を対象にペントバルビタールナ トリウム注射による睡眠時聴性誘発電位を指標とする 聴力検查で好成績を発表し, 乳児他覚的聴力測定の有 力手段になると述べた。

松崎等（東大）は脳波聴性反忘の発生機構の解明の 目的で, 聴覚刺激と視覚刺激の相互作用を検索し, 聴 性反応の遅い成分が視覚刺激によって抑制を受ける事 実から，この成分が皮質に起源すると述べた。これに 対し吉江は閃光刺激によりおこる脳波の pattern の 変化及び誘発電位の変化を質問したが，松崎は lowvoltage fast activity $の$ arousal pattern 示し たと応答した。

林等（東大）は麻酔のために使用するミンタールの 誘発反応に及ぼす影響につき観察し，III期（低電位速 波期）に誘発電位が出現し易いと結論した。これに対 し田口は誘発電位は Dement-Kleitman の $\mathbb{I}$ 期に振 幅最大となり，かつかなり媣い睡眠時にもよく出現す ると, 演者之やや異る成績を追加し, 徐波期には全く 出現しないと述べた演者之の相暴は, stage の分類の 違い，指標とした成分の違いによるのではないかと質
問した。これに対して林は, 深度は脳波 pattern の みから分類したこと, 指標は最大の振幅をとったこと を述べた。また鳥山（東大）は更にこれに追加して， 麻酔深度の分類は研究者が話しあって統一して研究を 進める必要があることを述べた。(広瀬毅)

\section{第 2 群}

（演 5 ）。第 1 音に引続き第 2 音を与えた場合，第 2 音が第 1 音に影響される現象は語音聴取や聴覚系の機 構を究明する上に一つの手掛りを与えてくれている。 島田(信大)は 2 音からなる 1 対の音刺激を与え脳波上 に現われる第 2 音の “掠そい成分” (v.p) を指標と して，聴覚路の回復過程を観ようとし，(i) 1 音と 2 音 との時間間隔による比較をし，v. p が可成り長い回 復過程をもっていること, (ii) 1 音と 2 音を別耳に与え た場合と同側の場合では, 別耳に与えた方が第 2 反応 振幅が大となる。(iii)睡眠時 v. p は覚醒時よりも大と なり, 意識水準の変化とともに変化すると述べた。船 坂（東大）は(i)に関連して, 約 $3 / 4$ 秒で後発刺激に見る べき影響はないと追加し, 又加算回数について40回で は不足ではないかと質問したが, 島田, 吉江（信大） は二種装置について検討した結果40回で充分であると の結論を得たと応えた。

（演 6 ）。4〜 5 才を中心とした幼時聴検は方法論的 に学会でも一応充分研究された感がないでもない。従 って研究目標も乳児, 新生児と次第に年令も下に移っ てゆく傾向にある。井村（京府大）は生後 5 日から 12 ケ月までの乳児に電気刺激による聴性条件反応形成の 発達過程を知り, 臨床一の応用を行うたが，0才で全 例に条件形成可能なこと; そして extinćtion は6 6 ケ 月頃に多くみられ 7〜8 ケ月では acquisition trial がより必要で, 最適回数は40回であるなど興味ある成， 績を報告した。荒山（信大）は 6 時間〜20日迄の新児 の浅眠時可視聴性反态を観察し，井村と同にく $60 \mathrm{db}$ 前後に反态檤を得たと追加した。 
: (演 7) 太田（慈大）はポリグラフによる骨導測定 を1ケ月〜19才の群を成人について行ったが, ”何分に も検查項目も多いことと，'測定值に変動が多くみられ るであろうことなどから個々の代表例や具体的数値の 説明も少く, 統計处理数值の結論的揭示だけでは, は っきりいって今一つ解説説得力に欠けるららぬがあっ た。荒山（信大）は乳幼児のレシーバーの圧抵につい て質問したが，太田から篅密な意味で一定は不可能か と思うが子供用レシーバーを特製しているとの応答が あった。骨導測定自体についても色々と問題のある所 であり，今後の詳細な報告を待ちたい。(柴田象太郎)

\section{第 3 群}

'演題 8 に対しては久保から演者と同様な值が，正常 耳”, 難㯖耳についで得られたとの追加があり，また千束 から，高音部で 2 分法をとった根拠にういて質問があ った。これに対し，高音部の変動は 1 つの周波数では大 きいので 2 分法をとったとの応答があった。また中村 一品，单一周波数で $10 \mathrm{db}$, 平均值で $5 \mathrm{db}$ 差在有意と

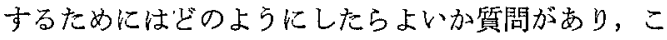
乣に対し $5 \sim 7$ 回測定する必要があるように思われる との応答があった。本研究は29例につきそれぞれ50回 域值検査を行なった労作であり，患者の聴力が本当に 良くなったのか否か判定するための基礎資料として貴 重な研究と思われる。その成績から受ける印象はきく 人によりいろいろであろうが，評者は次のようなこと を考えさせられた。即ち，本研究でとられた測定法は

（特に明記されていないが）おそらく純音聴力測定基 準によったものと思われるが，本研究でしめされたよ らに, 3 日間連続して測定し, そのうち初日の值をす てて, 2,3 日目の值を平均するようにしても, 単一周波 数の髙却限界が $10 \mathrm{db}$ をこえ, $15 \mathrm{db}$ 以上変化しなけ

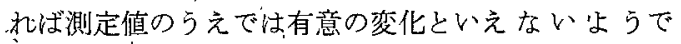
は，臨床的に種々な検討を行ならために不都合な点が 多いのではないかと思われる。従って，純音聴力測定， 基準を改良して，いま少し精度の高、測定法，あるい は測定值の評価法を普及する必要があるのではないか と考えさせられた。

一演題 9 は， Rintelmann の実験の追試であり，高 音部から低音部に変化させる等条件をかえたデータ はないとのことであった。また坂部から rise-fall time がいくらか，断続音構成因子の何が本現象に影 響すると予想しているかとの質問に対し；前者は 25 $\mathrm{msec}$, 後者に対しては on-time の関係が大きいので
はないかと考え検討しているが結論を得ていないとの 応答があった。

演題10に対し：中村から，E玄とはなんの略記か， 第 4 図のタテ軸岒なを $0 \mathrm{db}$ としたものかとの質問 があり演者から，「ET は effective time の略で, ある音が sensation に達するには一定の critical value がある。この呈示時間のすべてが積分されるの ではなく, 先行音が存在する場合, レベルによって時 間的積分効率が変わって来る。これに対しての言葉で す。また第 4 図の夕テ軸は，200 $\mathrm{msec} の$ 閾值のレベル を $0 \mathrm{db}$ として基準にとったもので，音圧レベルとの 差は $0.8 \mathrm{db}$ である。との応答があった。本研究注演 者等が数年来発表している一連の研究の一部である が, このような演題に対しては, その研究発表の理解 をたすけるために，前回までの研究成果等を説明する 若干の時間を規定の演説時間以外に割り当てる必要が あるのではないかと考えられる。

NI-TTS の恢復時間, 恢復様式が著明に変化する負 荷音の強さがあること徒来から度々指摘されている が，演題11は，その関係を $2 \mathrm{db}$ ステップのホワイト ・ノイズを用いて検討したものである。レベルを一定 にじがたいノイズをあえて使用したのは, 他の研究と の関連上ノイズを用いる必要があったためとの説明が あった。

演題12注, 耳介笳の随意收縮が可能な人では, 耳介 筋の随意収縮時に耳内筋の収縮がおこることを，NITTS を指標として検討した研究と思われる。耳内筋 のそのよりな収縮が伝音能率に括よぼす影響を，NITTS の変動量から逆算するこころみ注今回はなされ ていないとの応答があった。(中村賢二)

\section{第 4 群}

本群は主としてリクルートメント現象と関係あると 考えられる検査についての検討が主であり，そのため に討論注これらの問題にのみ集中した。

鈴木（弘大）は自記オージオグラムにあらわれる振 幅を正常人について，音の性質，音の減衰方法などの 面より検討を加え，持続音の方が断続音よりも振幅が 小さくなると述べたのに対し，新井（信大）は同様の 検查を行ったが振幅の差住極めて少なかったと述べ た。これに対し鈴术注良く訓練された正常者を対象に 使用したので差がでてきたといら見解を出したが，こ の点は今後更に解明されてくるものと思われる。

SISI、テスト (short increment sensitvity index 
第10回

test）は検查方法としては新らしいものの一っであり 現在まだ方法そのものも確立された一定の方式はな く，本間（弘大）や滝本（名大）は音刺戟を20回与光 ているのに対し，服部（神戸大）はむしろ10回位の方 がよく，しかも at randomに与えるべきだと追加し た。また adaptation についても一定した所見はな く，この検查がリクルートメントそのものを測定して いるか否加については米解決としても，感音性難聴の 多数例で本検査で陽性になることは本間, 滝本, 服部 汉び新井（日大）らの全てが認めていた。（河村正三）

\section{第. 5 群}

この群注短時間音を用いた実験 3 題が集められてい たが，終りに座長(河村正三助教授)の発言にもあるよ うに，「二般の方にとってはあまり牂染がなく，非常 に難しいところで判りにくいところが多々ある」群で あった。座長が最後に各題についてその要点を述へて 各演者に説明を求めたのは適切な処置であった。

$\lceil 17$ 断続音の域値にお汀る両耳加算効果」（細田, 京大）江両耳に短時間音を各耳の域值の強さで与え, 両耳加算効果を Békésy 記録で示した。その際雨耳 への短時閒音の一方を遅延させると遅延の度により加 算効果が影響をうける。また $20 \mathrm{msec}$ の音を $20 \mathrm{msec}$ の delay で与える, 即ち $40 \mathrm{msec}$ の音を二分して $20 \mathrm{msec}$ 宛各耳に相ついで与えると，そのときの加算 効果が, 単耳聴の場合の $40 \mathrm{msec}$ 音と $20 \mathrm{msec}$ 音との 域值差 (単耳の temporal summation) とほぼ等し いことから, 両耳の temporal summation がおこ っでいると推定しだ。鰕原（東医歯大）はこれに対し 両耳聴の場合刺激が二つであるから域值のとり方に疑 問があり，この場合注域值で注不合理で確率から考え ると $75 \%$ 域值をとるべきであると発言した。この問題 活過去の両耳効果の諸実験に捛いても気付かれていな 、ことで，両耳聴をとり扱ら上での新しい問題として 検討を要することであろう。

「18 音刺激頻度の把握能力について」(佐藤; 東 大） ほ断続音の断続回数を16〜25回数えさせ、て，その 、誤認率を正常ならびに老人について検討した。断続率 が 1 秒 5 回以下とそれ以上とで誤認率に差をみとめ, 聴性反応時間との関連づけによっっこれを解明した。 今後中枢性難聴者に用いてその成績が発表されると，思 われるが，興味のある方法である。

$「 19$ 短音の域值と大きさ」(萩原, 名大) 矤短時間 音の域值の測定の後, その loudness の測定を二音
比較法を用いて行った。演者の要約するところによれ ば, auditory function には空閒的積 分能力の強い ものと時間的積分能力の強いものとがあり，これが loudness を大きく感じさせる。それに対して中枢か らの抑制，末梢からの㧕制がありここ 4 つの因子が からまりあって loudnessを形成している。だから城 值附近の intensity の弱いところと, intensity の強 いところでは同じ態度をとることはあり得ない之いう 考えに基いているようであった。この考光を実験式で 示し一つの理論を生みだそうとする努力に敬意を表す るが，この問題がすでに゙多数の先人の実験がありそこ から発展した理論があるため，その上江立って更に一 歩を進めることの難しさが感ぜられた。竹内（京大） は実験式に関して二三の疑問を質したが，今後ともこ らマ:ら問題に興味をもつ人達の真㙯な発言を期待した い。(太田文彦)

\section{第 6 - 群}

第 6 群は補聴器, 聴能訓練等の, aural rehabilitation に関する部門である。最後の米国におけるオ一 ジオロジーは戦傷者の aural rehabilitation プロ グラムにおいて, 耳科学と言語病理学を母胎として 生れたといっても過言ではない。 audiology の研究 によって得た成果を障害者の福祉にいか役立一てる かといら問題は，今後更に広くとりあげられ㸚ばなら ない。補聴器の装置には，海野の報告のようにす、゙に 言語を修得した者に対する適応テストと早川，山口の” 報告のように言語修得期の幼児に対するものとがあ る。前者住しては medical audiology の立場汃 らわが国でも多くの研究が行われてきたが，後者に 対しては, 今後耳科医の積極的な関与によって発達さ せねばならぬ課題であろら。高木は Houston Speech， Hearing Centerをス.ライドで紹介した。同セシター、 は Jerger, ·Bangs の名前でも名高い。

第 6 群に対しては質疑応答が活発に行われ，まつ海 野に対して, 角田より補聴器の未経験者には一回の適 合テスイだけで装用に対する予後は決められぬこと又 高木も補聴器の訓練による慣れを考慮すべきことが追 加された。これに対して岡本より処方終了後は経過を みて ARC の使用を中止，慣れに応じて出方を増大寸 るとの応答があった。早川らの聴能訓練プログラムに 対して谷は補聴器連用によると考えられる聴器障害の 1 例を追加し，これらの早期検出について質問があっ た。角田は障害予防のため訓練は片耳でのみ行ない， 
早期検出には，DAF tapping test を行って簡便に 病的順応現象の検出に勉めていると応答した。

阙本上り成人にも聴能訓練は可能かとの質問に山口 より C.I.D.に成人プログラムのある旨の応答があっ た。成人の聴能訓練プログラムには米国陸軍レハビリ テーションセンターで行はれた Carhart を中心とす る系統的なものがありわが国では国立聴力言語障害 センターで18才以上の成人に対して現在行っている。

（角田忠信）

\section{第 7 群}

学童難聴の問題は，かなり古くから取上げられてい るが，難聴学級開設以来再びクローズ・アップされて きた感がある。谷 (東京学芸大) は東京都における新 入学児童に対する聴力検查の現状を 報 告し, 検查設 借, 方法, 条件, 判定規準等も不統一や不都合な点が あることを述べた。又言葉 (咡語) による撰別検査法 の成績に言及し, 就学時に特殊教育を要する子供を見 出す方法として優れていることを述べた。特に新入児 童を対象とする場合, 各種の条件を考えると撰別のレ ベルとしては，やはりオージオメーターの $30 \mathrm{db}$ 位が 適当で $20 \mathrm{db}$ は実状に適さないと考えられる。

脳性麻㿉に扝ける聴力障害について服部（神戸医 大）淦聴の頻度, 聴力型, 原因, 聴力障害部位につ いて述べ, 特に最後の項目に関し, 各種精密検査の結 果から, 内耳性難聴を主とするものであると結論し た。座長より検査成績の信頼性に関し僙問があったの に効し演者は脳性麻哽の子供の IQ 值は数值をそのま ま採用することは出来ない，大てい低く評価されすぎ る。又大学時に IQ の余り低いむのは入れていない。 3 年間 3 回の測定で結果の再現性が高いことからも測 定成績恃充分信頼しらると応答した。

精神薄弱者の聴力検查成績について大和田（東京学 芸大）汇(1普通の純音検查でどのていど信頼しうる結 果が出るか(2)知能の発達に悪影響を及ぼす程の聴力障 䨐の有無, (3)聴力障害の程度の点を追究した。721 名 (1442耳) 中検查不能404耳 (28\%), 信頼性のないも の 250 耳 (17\%) 合計 $45 \%$ でこれは精神年令の低いほ ど多い率を示した。純音検査で高い域值を示した者の 中, 語音域值はずっと低いものが見られた。結局検查 不能あるいは不確実群の成績が得られないと第 2 , 第 3 の問に対する答㥂られない・と述べた。これはなか なか困難な問題である, 第一に難聴の定義から問題と なろう; 即ち所謂反射を利用した他覚的方法によって
得られたものを直ちに聴力といってよいか；たとえ聴 覚系が完全でもこれが受け入れられず，利用されね ば, 音や信号の意味が理解されねば, 音注存在しない のと大差ないからである。座長から検査の困難性につ いて質問あり，演者は意志表示出来る者忊丁寧にやる と信頼出来る結果が得られる, IQ は検査の可能, 不 能の指標に必ずしもならぬと危答があった。前 2 題に

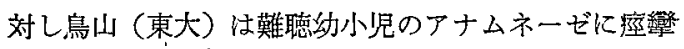
のあったものが20\%はあることから，それ等の子供に は脳に何等かの器質的障害があると考えられる旨追加 があった。痙彎発作が直ちに脳の器兴障害と結びっく かどうかは疑問の余地があるのでこの\%は幾らか割引 く必要があると考えられる。端田は患者の聴力検査を 無響室内で行うことに対し, 人閒注日常いるくなるな騒 音の中で聞いているのだから厳重な無響室であればあ るほど，そこで得られた結果は実際に即したものでな いことも多いと述べた。これは補聴器の適応その他で 少しは行われているが, 充分コントロール出来方 noise を信号と mix する負荷聴力検查が日常の検查 としてもっと行われるようにする必要性を感じさせら れた。柴畤等 (大阪市大) 注娃娠母体にSM 投与され た場合その出生㫛の聴力がどうなるかを臨床例から追

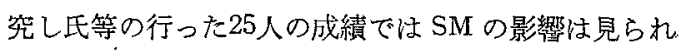
なかったが，今後更に各機関からの多数の報告を待た ねば結論は下し得ないと結論を保留した。充分に留意 すべき問題で産科医，小児科医との緊密な連絡がなけ れば解決注出来ないであろう。本群の最後は, 万うあ 者のタッピング動作特性々ついて角田等 (国立聴力言 語障害センター) の興味ある報告があった。各種のパ ターンで 30 ” 間タッピングを行わせると正常者と後天 整は略々同質的であるが，先天警では正打率も低く練 、習効果が僅かしか認められぬ等異質性が認められた。 この差は聴覚フィードバックの確立とそれに伴らリズ ム感賞の形成, 聴覚使用期間の差によるものと演者は 述べた。後天㢣といっても $3 \sim 4$ 才以下で全奛となる と次第に言語を失らし7〜8才以下では言語, 構音む. 乱れてくるが演者の取扱った後天整は何才位に始まっ. たものであろうか。動物実験で聴覚皮質領野を障害さ れると純音域值の上昇はなくてもパターンの弁別が障 害される場合が報告されている。演者の実験がこれら と何か関連があるとすれば更に興味ある問題が考えら れる。(服部浩)

第 8 群 
この群 (座長堀口申作教授) には, 音響刺激が内耳. その他に及ぼす影響を形態学的もしくは組織化学的に 追及した 4 題が並んでいる。

音響刺激の感受器官である聴器が，その過剩刺激に よって障害されることは, 経験的にというより,むし 方常識的にだれでも知っていることながら，その mechanism はと聞かれると，一概に言うことは難か しいがと先づ断ってから，その交とも余りうまい返事 にはならない。

それはそのはずで，刺激音の種類やその与え方によ ，って随分ちがった影響が見られることも事実だし，ま た何といっても個体差が著るしい。これには刺激と障 :害との間に大きく自律神経系も関与していることだろ らし，その他にもいくつかの因子があると思われる。 また一過性の聴力低下と不可逆性の障害とを劃する一 線が，どのような病態に存するかも見極められていな いから，明快な説明を求める方が無理である。

しかし, 音響性障害の治療の基本を壮, 聴器細胞の 化学的病態にまで遡って考えようという努力は絶えず 続けられていて, 本群の発表も, 組織化学的あるいは 全身体的な協同関係に注目した地道な研究のあとであ' る。以下順を追って紹介する。

最初の演題は日本医大坂下等の「音響刺激による 脳下垂体及び副腎機能の実験的研 究」で，音響性の stress によって交感一副腎系や脳下垂体前葉一副腎皮 質系が影響を受けて生体内分泌機能に変化を来すので はないかといらことが検討されている。

その結果は, 与えられた音響性刺激法，下垂体前葉 の向副腎皮質ホルモン (ACTH) の産生を大ならし め，これが副腎皮質を刺激して 17 . OHCS の分泌を促 す傾向があることを示しているが，聴覚並びに内耳組 :織の障害は著明ではなかったので, 直接難聴との結び つきを云々することはさて扔くとしてを，音響性障害 対策の一つとして hormone の平衡を考虑に入れなけ ればならないことは, 自律神経や血流の平衡対策と共 、汇無視出来ないものであろらと考えられ，内分泌機能 と聴覚障害との関連については非常に複雑なものが予 想されるだけに，今後の追及が大いに期待される。

次は医歯大難聴研庄司等の「地雷爆発によるモルモ ットの聴力障害の病理組織学的変化」の発表があっ た。これ注地雷爆発がその近くに置いたモルモットの 聴器にどのような病理組織像を生じ;またこれが㯖覚 機能とどの程度相関々倸が見られるかを種々検討して いる。
その成績をみると，戦車外に厧いたモルモットで中 耳伝音系に高度の外傷を来しているのは, 強烈な爆風 によるものであろうが, 興味あることは強大音響刺激 の動物で, 聴覚の変化と有毛細胞の損失との間に比較 的対応した関係が示されていることで, 試獣を固定し ておいたこの実験でも個体差が可成り出てはいるが, 音響の程度と聴器障害の発生部位などにいくつかの知 見が得られている。

続いての演題も医歯大難聴研の発表で, 秋吉等の 「音響負荷モルモットの恥力障害と蝸牛有毛細胞のコ ハク酸脱水素酵素の変化について」であった。

強、音響を与えた場合, 血流速度が低下し血中の酸 素分圧や細胞の酸素利用度に対して呼吸酵素の役割は 注目されるところであるが，この発表では酵素活性の 低下所見は散発的であるが比較的広範囲に亘る傾向が あることが見出されている。

コハク酸脱水素酵素活性汇ついては蜛牛迷路細胞の energy 代謝の状態をらかがう一つの手段として多く の研究が行なわれているが，一般に内毛細胞より外毛 細胞のそれが活性大であり両細胞間で営なまれる物質 代謝の差異が推定されているが，この障害実験でも外 毛細胞の場合より内毛細胞に低下が少なかったという ことは興味深いものがある。

最後の弘前大今等の「白色騒音負荷によるモルモッ 卜内耳の核酸の変動に関する観察」では, 従来の観察 方法が主観的観察に陥り易いといら久点を補らため に, 紫外線吸光度測定で客観的儿測定して, より正確 に近い表現をするように努められた研究であり, 同一 標本では充分その目的を達している。

この実験では120 125phon の白色騒音による負荷 で毛細胞，血管条細胞ならびにラセン神経節細胞内の RNA, DNAの濃度分布の変動を時間的に観察して, RNA の変動には比較的はっきりした型が得られてい るが，DNA には余り変化を認めていない。こうした 研究は近年次第に盛んになってきているが，このよう な定量的な観察に電影的な細胞の微細研究が相ま口 て, 今後一段と進歩がもたらされるであるう。追加, 質問なし。(三宅弘）

\section{第 9 群}

最近の内耳の組織化学的研究に一つの著しい傾向が 観取されるように思われる。以前は, 内耳における酵 素の検出，大ざっぱな分布を見るに過ぎなかったが， 最近では, 病的状態における酵素の変化, 内耳各部位 
にとくに各回転間におげる分布差; 内耳機能々酵素活， 性相互の関連性等の問題が取扱われるようになり!’形 態学と組織化学, 及び, 機能との関連性が少しづつ明 らかになりこの分野に扔著しい進歩がみられて いる。とくに本邦では，各大学で多くの注目すべぎ業 績が輩出し，その内容で世界でもトップレベルにある ことはすこぶる喜ばしい。今回の諸演説の内容は，い ずれも高いレベルにあり，演者の明快な講演とあいま って，甚だききごたえがあった。京府大の中村，西村 は，D一D系站、ウスに $3 \mathrm{H}$-tymidine を注射して, 胎览の諸胎生期の内衣諸細胞えの $3 \mathrm{H}$ の incorporation、を auioradiography によって観察し; 細胞の 分化が始まる前に， 3 Hを注射しても分化后の諸細胞 には，放射能が検出されず，分化が始ってから検出さ れることを報告した。この研究は, '内耳諸細胞の分化 のメガニズムの動的な状態を, 物質代謝の面より追求 する一方法を示唆している。解像力を上げるには, 厚 い標本が必要なことがら本演題に東大の長倉より, 標 本の厚さについて質門方あった。演題は, やはり京府 大の中村他によるモルモット内耳酸性ムコ多糖類に関 する研究で, 'カナマイ中毒時の内耳諸組織中の核物質 の変動を $\mathrm{S}^{35}$ の incorporation 及び, 組織化学的に 钼察した。tectorial membrane $と$ osseous spiral lamina の多糖類の滅少が著明でかつ, 基礎回転に著 しかったという。この事実は，重要な意味を含んでお り，カナマイが，内リンパに出現することを想像させ るとともに，また有毛細胞の变性が下方回転に著しい といら东実の解明えの重要な示唆を含んでいる。これ について, 新大, 小出の質問があり演者は, ムコ多糖 類の減少は，下方回転程著しいことを重㸚て強調し た。また京府大の水越は, カナマイ中毒の問題では, ガナマイが，内耳にどんな大り方をし，どの様に生化 学的膜構造を disturb するかを調べるこ主は，将来 の重要な問題とした。演題35では蝸牛のATP-ase の 問題が九大の河田他によってとりあげられ，有毛細胞 では, ATṔ-ase が外毛細胞に多いことが明らかにさ れた。小出によってコハク酸脱水素醳素も同し分布を して㧍こることが確認されて㧍り，種々病的状態机 いて, 外毛細胞の受傷性が高いことと, 細胞の代謝レ ベルとに相関性が示唆される。ほた, 演者は, ニコチ ン゙，カリウムを投与すると内有毛細胞に特に強い活性 があらわれると述べ：ニコチー酸とカリウムの併用が 特に有効で，夫々を単独で投与しても，左程有効でな いという。招そらく，カリウ文吕 ATP-ase 促進的
に働くのであろらとの考察が下されたが, 。れれ対 し，新大の小出より，カリウムの效果としては，その 外に透過性の変化という面からも考えてみる必要があ ろうという意見が出された。医歯大の佳藤より染色性 は，各回転で一様であったかという質問があったが， 今後の問題として, 京府大の水越よりATP-ase の組 織化学に対する豊富な経験からの意見の開陳があった が,- ATP-ase に限らず組織化学の確実な成果を得 るには，充分な注意艻必要なことは，マ゙うまでもな い。九大の河田, 星田; 原田は, モルのコルチ氏器, フォスフォリラーゼを観察し，下方回転では，活性が. 弱く, 上方回転では, 強いこと, 及び, 外毛細胞は, 内毛細胞より活性が強いと報告した。新大，小出，医 歯大，佐藤より質門があったが， しかし，非常に面白 い結果といえる。今後, もっと例数を重社て決定的結 論を期待したい。モルのラセン神経節の神経に関する 電顕的観察が千葉大の北村, 金子, 神田の諸氏によっ てなされ，有髄神経について報告があった。電顕像と いらのは, artifactの問題が常にからんで来て, 3 人 の納得する成績は, 仲々得難いといえる。諸演題を子 りかえってみると, 明らかな, 1 傾向が認められよ う。すなわち：演題，34，35，36共に対象とする酵素 は違っても, 内耳における部位による代謝構造の差異 を漸次明らかにしつつある。この方面に研究が伸びて 来たこと注, 近年の一収獲とい党る。しかし, 組織化 学的研究にも, 限界があるので, 電顕的研究によっ て，その及代ざる所を補ら必要がある。この点，千葉 大の研究に期待したい。

(小出靖)

\section{第 10 群}

この群は内耳電気現象, 及びその機能を保持すると 考えられる血流を観察して聴覚をみた演題が収められ： た。

群を開始するに当り座長（大和田教授）より内耳で の各種電気現象についての解説がなされたの洁甚だ有 益であった。

No.38及び 39は共に蝸牛回転よりの E P 同時記録に よる報告である。勿論これにはD C 記録の為に電極相 互間の干涉問題が解決されてのことであるが, 電気生 理学的に聴覚機構を解明するのにこのような立体的方 法む1つの方法と考えられる。

No.38 柱特に S P の態度につき今回は主に第 1 及び 3 回転での比較意試み，その間に明かな差を認めた。 
質疑にもSPに関しての解読の検討がなされたが，音 圧, 周波数によって回転別で異るが，一定傾向を示す こと, 発生部位が有毛細胞と考えられる事等から発 生様式には基底膜振動との関倸を, 意義としては loudness と周波数弁別に役立っていると考え礼ばな るまい。

No.39 は 2 回転E P 同時記録を利して, 互のE Pの 独立性, 被影響性を他方回転血管条損傷により検討し たものであるが，特に静的状態のみでなく anoxiaの 動態で比較した所, 興味ある事に,下方回転は上方回転 損傷には被影響性がないが，逆ではあるという結果が 生じ，E Pが血管条を源とす、る今日の考え方では内耳 血流の状態, 影響性を知る端緒となり得ると考える。

No.40 昨年に続き九大による自律神経機能と内耳機 能との関連を見出さんとしてインピーダンス脈波計を 応用した試みである。自律神経に働く薬剤が内耳電気 現象に影響する事実は既に九大，大阪鉄道等の報告が あるが，今回江自律中枢刺激と音刺激が共に脳及び内 耳への血流変動を惹起すること, 更に注脳血流でも音 刺激では側頭葉での変化が著しかった点はこの間の関 係を充分推察せしめるものらようであった。更に一般 に自律神経平衡異常といわれる疾患との病晁について の究明がなされて行くことが望まれる。(安野友博)

\section{第 11 群}

一演題42 湔庭階, 鼓室階の間に通電して E P を人 為的に変化せしめると, 高い相関性をもって $\mathrm{CM}_{1}$, $\mathrm{C} \mathrm{M}_{2}$ が変化することから, E P は C Mの増幅因子で あると結論した。通電の最高值は $200 \mu \mathrm{A}$ (菅; 質 ! 問)。C M 2 は P が負の最大值を取って10-15分後に 検討した（質問；大内）と述べた。CMとE Pの物理 的関倸を問題に取り挙げたものである。

演題43一は電気的圧力計により内外リンパ圧を連続 的に記録し, 種々条件下の興味ある成績を報告, これ に内耳血流, 体液平衡状態等が関与していることを薬 物を用いて明らかにした。又強大音響負荷時の成績が 一定でないこと（質問；大内）は麻酔深度, 自律神経 系の差等によるものと答えた。

演題44 は伝音障害, 即ち砧鐙関節不完全離断時の C M 観察七, $1500 \mathrm{cps}$ 以上の高音障害を認め, 不完 全離断した関節面の接着程度でその值いが異なること を述べた。誘導法は（質問；大内）は鼓室階頸筋誘導 である。

演題45 は鬼で，永久電極法によるC Mが騒音負荷
第10回 日本オージオロジー学会総括報告 227 にようてらける影響を20一-40日間にわたり観察し, 始 め fatigue による低下, 次に adaptation, habituationによる一過性の恢復, “次に漸進的低下即ち damageをみるといら。この一時的恢復の原因（質 問；三好）に耳小骨能の関与が考え方れると述べた。

演題46 はイオン泳動法によってKチャンネルブロ ック剤 T E A を有毛細胞, 中央階に作用させ C M の低 下を, 又 $\mathrm{Na}$ チャンネルブロック剤-tetrodotoxin の投与で $\mathrm{N}_{1}$ の選択的減少を認めた。この成績は $\mathrm{CM}$ と A Pの関係, そのエネルギー変換機構の解明に手掛 りを示す。泳動通電の影響 (質問; 大内) は無視出来 ると述べた。

この群往内耳電気現象の本態, 相互関係の究明, C M.を利用しての臨床病理的問題, 更に内耳圧の問題等 基礎的にも重要なテーマであり，これら現象と実際の 聴覚との関係 (質問, 三好) 解明すると共に, 今後 一層の努力によって実際的な応用に迄発展することが 望まれた。(森満保)

\section{第 12 群}

聴覚中枢に関する本群の研究は, いづれも超微小電 極法によるものである。

棚橋 (名大) は蝸牛神経核より単一神経線維の純音 刺激に対する応答を記録し，一耳に引きつつげて二 音を入れた場合の応答性の変化を追求した。聴中枢路 に㧍けるパルスによる情報の伝達の研究には、コード 化の様相をきわめることが, 重要であるが, 氏の研究 は, 二音相互の影響といら観点から, コード化の様相 を追求せんとしたものであろう。一音刺激による反応 は, 先行する条件刺激音によって, 主として抑制され ることが明らかとなった。ただ，氏も述べているよう に，この抑制機構の解明が今後の課題である。なおこ れに対し, 座長より,「耳小骨笳に対して, 筋弛緩剤 は複雑な作用をもっているので, 笳驰緩剤の種類によ っては耳小骨筋の影響を無視できるとはいえないが， どらか」。船坂（東大）より「時閒的加重の点につい ての考えいかん, 麻酔剤としてクロラロース使用の理 由如何」との質問があった。

渡辺（東北大）结, 内耳神経の自発放電は耳鳴と、 かなる関倸にあるかを追求した。耳鳴を誘発せしめ 得るといわれている強大音響, 中耳腔陰圧, 内耳加圧 を負荷して, 自発放電の変化を調べたところ, これら の条件下で注自発放電の著明な増加はみられなかった といら。大内教授から「自発放電が耳鳴の原因である 
と考えるか。 内耳毛細胞を直接刺激する方法について の考えはあるか」と質問があり，これに対し，「内耳 神経の自発放電洨変動しにくいものであり, 耳鳴の原 因としては否定的である。内耳刺激の方法は考慮中で ある」の応答がなされた。

加藤（新大）は 362 箇の内側膝状体ニューロンの応 答をデータ処理用の電子計算機により処理した研究 を述べた。超微小電極法の欠点は, . 核の全体としての 活動を予想するのに不適当であるとされており，その 久点をおぎなうために同一の神経核より多数のニュー ロン応答を求め, その結果を統計的に処理することが 近年になって行われている。氏の研究はこの傾向に沿 ったもので，きわめて高度の技術を用いたものとして よい。その結果, 内側膝状体の反応型式は皮質ときわ めて似ていること，また二篁の忘答野を有するもの， 音の強さによって反応型の異るもの, 二峰性の応答野 を示すなど，特異的な反応を示すものの存在が明らか にされた。これから氏は内側膝状体では下位中枢から 送られてきた情報内容の integration が行なわれて いる可能性を推測しているが，この点は容易に首肯で きよう。質疑応答で森満（九大）は「レクルートメン 卜現象と関連する事象はあったか」と尋ね,「はっき りしない」と応答があった。を船坂（東大）は「皮 質では，長い潜時のものは反応性の変化をきたし易い が，内側膝状体ではどうか。音の周波数を変えると反 “応型相互の移行が生ずるか」と質問した。これに対し 「反応性が不安定なものは潜時の長いものに多い。周 波数の異った音に対して異なった反忘型で応ずるもの もあるが，異なった強さに対する程明確なものではな い」との応答があった。

総じていえば, 超微小電極法がわれわれの領域の研 究に導入されてまだ日は浅いが，これは中枢神経の働 きについての研究には必須の研究方法である。従って 今後の関係者の研究の発展を大、に期待した认。殊に いろいろの生理現象の神経細胞学的な機構を明らかに することがこの方法のレー・゙ンデートルであるだけに 一層の努力が望まれる。(戸塚元吉)

\section{第 13 群}

本群では聴覚の生理又は病態生理に関する基礎的研 究の 4 題が報告された。 $49 ， 50 ， 51$ 番の 3 題はいづれ も東医歯大で以前より続けられてい・た研究の続報であ る。49番.は断続音と持続音上昇法, 下降法によって得 られた Békésy tracing の域值差に関して衝撃音域
值の強さ一呈示時間関係を調べたものであり，50番． は時間的に続行する一対の 2 音刺激に際しての第 2 音 の域値改善を単耳と両耳で測定して加算現象を調べた ものであり，51番は強さの弁別域を重ね合わされた衝 揧音を用いて测定し，DL值の本態について考察した ものであると理解した。演者等がそれぞれ主張してい たように,これらは感音難聴の診断という最終的な大 きな目的に沿った研究のそれぞれ 1 部分を占めるもの であり，臨床的意義は少なくないと思われるが，実際 にほかなり難かしい内容と表現が多ぐ，些か難解であ マった。もう少し時間をかけてゆっくり説明，てて頂きた いと思ったのは筆者ばかりではないであろら。

50 番に対して竹内（京大）は, (i) 第 2 音の測定条 件, 特に第 1 音が存在する時としない時との差, (ii)加 算の成立部位が未定であるということの説明, (iii) reference zero の点について質問があった。これに 対して演者及び鰕原（医歯大）から応答があったが, 質問者の意図と応答者のそれとの間に若干のくいちが いがあるように思われ，明確な結論が得られなかっ た。51番に対しては種村 (名大) から同様なテーマに 関する考えの追加が，立木（弘大）から実際検査に応 用する際の具体的方法に関する質問があった。

次に52番注竹内（京大）の雑音刺激に゙短か、時間的 空隙を作った時のその空隙に扝けるマスキング効果に ついての報告であった。これには解原（医歯大）が実 際に雑音が存在しない時 (空隙) でもマスキングとい う言葉を使用することの可否について質問した。演者 からは実際にマスキングであるか否かは何ともいえな いが，一応こういう言葉を使っ亿いるのであるという 意味の答えがあった。（立木孝）

\section{第 14 群}

。翼涇者のために聴覚の代用として皮膚の振動感覚を 利用する試みは以前からあった。広瀬（信大）は最近 進歩して振幅の絶対值が測定出来る振動子を用いて, 正常者の振動感の域値を身体各部で測定した。200c/s 附近が最も感度がよくて，それより低、周波数でも高 、周波数でも感度は悪くなる。振幅は大体 $0.05 \mu$ 乃至 $3 \mu$ の間にある。，この結果は従来の研究者の成績とほ ぼ一致する。又振動感の感度は身体の部位によってこ となるが, 顔面では口唇, 軀幹では胸壁がよく, 指先 は必ずしもよくない。渡辺（北大）の質問の応答とし て次のこどが判った。振動子の圧抵圧は $250 \mathrm{gr}$ であっ たがこれは装置の許容限界で，これ以上に圧を上げる 
と感度がよくなることが $250 \mathrm{~g}$ までの範围で確認され た。

鼓室成形術後の聴力の変化については多くの研究が あるが，鈴木達児（東医歯大）屾臨床例を統計的に検 討した結果, 術後日を経るに従ってオージオグラムの $2000 \mathrm{c} / \mathrm{s}$ 附近のピークが高音に移動することを証明し た。この術後の聴力の変化の原因を明かにするため に, 成形術後患者について外耳道に $40 \sim 50 \mathrm{mmHg}$ の 圧を加えて, 気導の変化をしらべた。その結果, 圧の 増加によって $500 \mathrm{c} / \mathrm{s}$ 附近のピークは $3000 \mathrm{c} / \mathrm{s}$ 附近に移 動することが明かになっうたこれは加圧によって皮弁 の弾性が増加したためと推論した。術後日を経るにつ れて，オージオグラムのピークが高音に移動する原因 も皮弁が日を経るにつれて乾燥し, 弾性を增すためで あるといら。なお, 演者は成形術後の高音下降性の難 聴は乳様蜂窩にできる腔によるものであることを，腔 を充鎮することによって証明したと述べた。中村（東 大）は,・外耳道腔の容積の変化が聴力にどう影響する かをしらべるには free field 聴力検查でなければな らないと指摘した。これに対し, 内藤 (阪大) が応答 し「free field での検查を検討したい。オージオグ ラムの上でよい方が，悪いものよりはよいに違いない と思らが」と述べた。中村の指摘の意味は正しく伝わ らなかったようである。

感音性難聴の中で回復し得るものとして注目されて いる乫発㜔聴の予後の判定に役立つ徴候は何か。井出 (東大)は発病以来の経過を36例のオージオグラムにつ いて検討した。良好例は20 30病日で回復し,多くは低 音と高音が同時に回復する。予後の悪いものの多くは 急墜型 (高音障害) であった。発病後 5 日以内で 500 $\mathrm{c} / \mathrm{s}, 2000 \mathrm{c} / \mathrm{s}, 3000 \mathrm{c} / \mathrm{s}$ でスケールアウトのものも予後 汢悪いとのこと。久保（大阪鉄道）淀例を追加し， 低音と高音の回復するものはよいが, 高音障害型で低 音だけ回復し，同時に前庭症状を伴うものは予後が悪 いと述べ, ここの両者の差異は病坚の部位のちが、にも とづくのではないかと問題を提起した。これに対し切 替（東大）'は高音急墜型で矓暈のあるものに前庭と蝸 牛基底部の障害。水平型で前庭障害のないものは hydrops ようのものではないかと推定した。山本 （京大）は治療法について質問した。演者はビタミン $\mathrm{B}_{1}$ の, 大量投与, 及びステロイド, A. T: P 血管拡張 剤を使用したものとのこと。

中村 (東大) は耳鳴に対する薬剤が有効が究うかを 判定するために偽剛による double blind 方式を試み
た。またこの検討に察して耳鳴の変化を客観的にしら べるために，ピッチ及び大きさの変化を狭帯域バンド ノイズによる比較法がよいとした。示された症例は偽 剤で好転した。要するに耳衣鳴は難治であるとともに，自 然治癒もあり又, 患者の主観によって耳鳴に対するわ うらわしさが変るものなのであろう。従って薬剤の効 果判定を厳格にするためには患者や検者の主観を除く ために double blind 方式や客観的耳鳴測定法が提案 されるわけである。一方中村は耳鳴の主観的要素に着 目して，治療に当っては，薬剤を用いると同時に言葉 による治療（ムンテラ）で「満足した結果を得た」と 述べた。又治療に当って患者の性格テストが必要では ないだろうかともいっている。古賀（慶大）は演者が 薬剤の有効性を実証的に厳密に追究しながらムンテラ については満足した結果を得たという点で㛜密さを欠 くのではないかと質問した。(古賀慶次郎)

\section{第 15 群}

語音聴力検查に採用する音源についての発表がなさ れた。

語音弁別能力検查にもちいる語表は被検者の能力に よる誤差をできるだけ少くし聴能をよく表わすため無 意味なことばが無作意に配列されている訳であるが， しかし日本語では一音節でも意味があるため，全く無 意音節といらことはできない。辻等はこの点をつきー 音節の有意性を検討した。国語辞典上でも有意であ り，又被検者む有意と解翻しうることばが多い。しか も有意と判定するための所要時間も検討されこことば の familiarity について論じた。しかし字で表わさ れたものと発音されたものでも有意性は変り, 又語の 配列でも有意性ができるのではないかと討議されたが 心理学的要素注まだ複雑なものがあろう。

発声法についても咡語と話声語とあり, 男, 女とあ り，音の強さを電気的に等しくしても語音の明瞭度は 異る。戴等は男女の違いを論じたが，この違いは基音 の高さの違、によるものが不明であり，豊田等は発声 法の違いによるものを論じ, かつ低調音, 高調音につ いても述べている。ことばのフォルマントとの関係づ けは重要であるがむつかしい問題であり, 又正常耳と 難聴耳とのききわけ方の相違むまだ今後の問題であろ 5 。

三宅等によっで現在語音聴力検査委員会で試作した 検查用テープと57, A, B との比較がなされた。大変 な手段を要する基礎的な研究をなされたことに深く感 
謝し, これを基に新らしい検查用音盤が早くできるこ とを期待する。(岡本途也)

\section{第 16 群}

演題注 3 題だがいゔれも後迷路の機能を追究しよう といら前向きの真摰な仕事汭かり。

設楽（東大）らは，単耳に立 P, H P 2 種類の歪 語音（語表注57一A，B）を聴力損失目盛 $80 \mathrm{db}$ また は $90 \mathrm{db}$ の出力で聴取させたときの（L P 明瞭度 $+\mathrm{H}$ $\mathrm{P}$ 明膫度) /(普通の語音明瞭度値) を呆却限界と比の 值加 A A , A B , B ל 3 分し, 明瞭度比の大きい A A 型には㯖力損失が大きさなると自記法振幅縮少例が多 く，音像移動弁別域值異常例代 A B , B 型が多いこと からこれも難聴細別の手掛りになる検查であううとい っている。神㥓（慶大）は自験例から雨語音明瞭度は 、測定「ばらつき」が大きいから充分に考虑されたいと の意見を追加した。

文珠ら（京大）は' 1 音節と 2 音節の 2 種類の数字 リストを作り，なるべく両耳に同時 (dichotic) に数 字リストの数字を聴取させその応答率加ら中枢聴覚路 の障害側,さららには障害部位診断への応用の土台をう’ くろらをいうもの。

これについては佐藤（警察病院）加らリスト作成上 の困難さ, 兩耳同耳聴取時の分離能の表方し方, 図 3 (p206, Vól. 8, No.3, Audiology) の左耳の曲線の 解釈の仕方について質問があった。文珠（京大）の応 答で拄 dichotic といっても雨耳時間差は 8 100 $\mathrm{msec}$ の差ができるといらことであった。また角田（聴言セ ンター）は，本検查法の聴取レベル，一判定法に改良の 余地があるのではないか，さらにリスト作成上の数字 の吹き込み間隔等について質問, 応答は時間ぎれで肝 心なところ注聴取不能。

相沢（弘大）は遅延側音効果に関する基礎的検討を. (1)数字の暗誦, (2)鍵打, (3)器楽演奏の状態でしらべ た。この結果側音効果注いづれの状態でも側音の物理 的な@遅延時間，(b)音压レベルが重要な意味があり， 側音効果の背景に聴覚路亡関倸ある監視機構が関与し ているのだろうとの意見であった。豊田（三重大）の 質問に答えて, 数字の暗誦では50〜 .1までの逆唱状態 で側音効果はでやすく，打鍵状態が側音効果の観察に 便利とのことである。側音効果はいままで詐聴検査法 の枠内で考えられてきたが, 演者梳側音による動作状 態の変化を聴覚路に関倸ある監視装置の変化に結びつ けようと狙っているる。仕事の進展に声援を送りたい。
聴覚中枢路の跕床研究は audiolegy の枢要な研究 課題で斬新な未開拓な分野 (今まで余り手をつけたが らなからた分野という意)である。この分野について， この総会で他の群にもみられるように，臨床という 困難な研究条件下で新し、勢力の人々によってすぐれ た研究内容の報告がみられる。頼もしいことです。右 顧左䃌'吉不必要。ひたすらに研究を前進させていただ きたい。(鰕原勇)

\section{第 17 群}

この群では三題の騷音難聴の問題が討議ざれた。北 大の渡辺注最近使用分增加してきたチェンソー，刏执 機について，その騒音の性質と使用者にみられる聴力 障害について報告した。これらの機械はいづれも騒音。 のみでなく相当尔振動を伴うものであり,この点につ いて横山から振動之聴力障害の関係につけての質疑が 出されたが，騒音と振動とを別々に切離して討論する ことは困難に考えられる。騒音による聴力障害の問題 はかなり古くから討議が重极られているが，そのいゔ れにおいてもこの振動といらもの無視することはで きなかったはずであり，騒音と振動の両者を厳密に区、 別することは一寸むづかしい。振動の間題としては使 用者にレイノー氏病様症状党呈するこえがあると堀口 はのべ，騒音レベルの大きいのに比し難聴が比較的軽 いのは野外使用ということによるのではないかと柏戸 がのべているが，他方これら使用者が大半注一年のあ る期間だけ騒音にさらされている季節学衝といら点に も多大な関係があると思う。また横山に䉼続音と連続 音の障害の差についで質問しているが，こ机注両者を 正確に比較することが現在の測定法の場合殊に断続音 において困難であることを考えると，相当むうかしい 問題といわなければならない。恩地からは外耳道の共 鳴といら面から noise spectrum では2000 4000cps 付近のレベルに特に留意すべきことが追加された。

騒音職場に一定以上勤務したものの侅力変化につい て横山が報告しているが，その対象（造船工）に掠い ては 5 年間に $15 \mathrm{~d} b$ 以上の悪化京示すのは以外に少 く，ただ 5 年前に比較的聴力が良好であったものにが なりの悪化をみるこしが多いといら。これ会話音域 についてもほぼ同椂であったというが，同じような騒 音環境で同じ期閣働、てい:ても騒音難㯖になる程度に は個人差がかなりあるが，最終的に注多くの人がほぼ 同じような騒音難聴になるということの裹付けになる， のではないかと考えられた。この調査から横山は聴力 
損失 $\mathrm{y},(\mathrm{db})$ と経験年数 $\mathrm{t}$ (年) 就業年令 $\mathrm{s}$ （才）の間 に $\mathrm{y}=27\left(10^{\left.0.007(s-15)+0.01 t-10^{-0} 0.01(s-15)-0.04 t\right)}\right.$ を出 しててるが，この年令補正を15才にした点について久 保から異議が注さまれたが，これ虫実測を七た母集団 から決めら机たことであって一寸討論の的が別のよう であった。また騒音性難聴と聴力の年令変化の問題に ついて堀口らから.も討論をされたが, 補償といった個 人の問題と統計的に一つの集団の聴力を処理す方点と ではやや，暴った意味に考えられた。

騒音性難聴にかかり易いことが前もってわかってい れば, そこのような人を騒音職場に配置しないことがの ぞましいことは，現在のごとく騒意性難㯖に治療法が ない現状より当然のことである。この一つの方法とし て千束は NITTS を利用してそれを決める簡便法を報 告しているが，この問題の討論住前日の騒音委員会で 充分に討論されたためか，総会場では問題になるよう な討論は全くなかった。(佐藤正夫)

\section{第 18 群}

67）68）の前 2 題は騒音環境下におろいて発生した急 性難聴を取扱ったものであり最後の69）注騒音難聴の 対策上, 問題とすべき点を総説的に述べたものであっ た。67) 河村 (東京労災) は overall 85phon から 130phon迄の騒音レベル下就業者にみられる発症急激 な難聴を急性音響性聴器障害としで括すべきことを 述べ，これは寧万騒音下従業期間が比較的短いものの 方に多いことを指摘した。この場合一般の suddendeaf との鑑別が問題であるが, 有害騷音環境下で起 った限り労災の立場としては補償問題があるのでやは り患者に有利になるよう音響外傷的取扱をすべきであ ろらことが述べられた。68) 菅（九大）は 2 年前に提 唱された iudustrial sudden deaf なる範囲に入る べき症例群について考察を加え, 本症が騒音職場に長 年月就業していない者にも発生していること，休腵 後, 職場に復㴆した途端に発生している症例も少から
ず，見られること等から；やはりこれらの急性難聴は 原因として騒音を除外しで考えられることはできない 旨, 強調し, 病理的には恐らく螪牛末梢血管系の破碇 に基づくものであるうことを述べた。横山（阪市大） は67）68）に示されたような騒音職場の急性難聴症例 についての追加報告を行った。立木(弘大)は所謂音響 外傷と所謂 iudustrial sudden deaf との間に移行 型とも言うべき症例があり，それらはすべて一群の疾 患であって，個体の音響受傷性を左右する因子の状 態, 騒音の曝露条件の変化等, 発生原因となるべき要 素の配分如何により異った出現を示すのに過ぎな、のの であろらとし, industrial sưdden deaf なる特定名 称を附するだけの要はないのではないかと述べた。こ れに対し，菅（九大）は日常, 音響外傷をを起すごこな しに長期間過ごしてきた程度の騒音下にあってしかも 急激に起る難聴症例主やはり，普通の音響外傷とは区 別して考光るべきであると述べた。69) 久保（大阪鉄 道) は騒音難聴の対策として, 単なる騒音嚗露の質的 量的構成のみで騒音の聴器に及ぼす影響度を評価する ことができないことを強調すると共に聴力管理は高音。 域平均值を以てこれを行うべきこと。中耳伝音機構は 本難聴発生に意義が少ないこと。内耳末梢血管系の動; 態に直結する自律神経機能が本症発生に重大関係を持 つであろうことをを指摘した。これに対し横山(阪市大) はメコリール・テストの成績の上からみて必ずしも自 律神経機能々騒音難聴進展とが並行せぬことを述べ た。河田（尤大） は最後に座長としての総括的発言を 行い, 急性音響性聴器障害就中 iudustrial sudden deaf なる症例注，それぞれの持つ tolerance が，何: 等かの防禦反応のッマジキによって隇弱していること により発生するむのと考えるべきであらうことを述 へ, 又久保 (大阪鉄道) の演題内容の中, 中耳伝音機. 構就中，鼓室小骨筋反射の意義に関してはやはり意義 が大きいものと考える旨の説明があった。(志多享) 